\title{
INTEGRÁLT REGIONÁLIS FEJLESZTÉS-FINANSZÍROZÁSI MODELL A NYUGAT-DUNÁNTÚLON ${ }^{1}$
}

\author{
(Integrated Finance Model for Regional Development \\ in West Transdanubia)
}

MEZEI KATALIN

Kulcsszavak:

területfejlesztési eszközrendszer regionális támogatások regionális és megyei fejlesztési programok fejlesztési források összehangolása támogatások elosztási mechanizmusa

Tanulmányunk egy olyan kutatás eredményeit foglalja össze, amelynek keretében felmértük, hogy a Nyugat-Dunántúli Regionális Fejlesztési Program megvalósitásának elsỏ három évében (2000-2003 között) milyen közvetlen és közvetett területfejlesztési források érkeztek a régióba, ezekböl a regionális program mely elemei és milyen mértékben kerültek támogatásra, milyen volt a források elosztási mechanizmusa és milyen lépéseket tettek az érintett szereplök a források összehangolása érdekében. Az elemzö rész után javaslatokat fogalmazunk meg a rendszer továbbfejlesztésére vonatkozóan.

A Nyugat-dunántúli Regionális Fejlesztési Tanács már megalakulásakor felvállalta a régióban folyó területfejlesztési és ágazati fejlesztési tevékenységek koordinációját. A kiindulópontot a Nyugat-dunántúli régió NYUTI által készített integrált, ágazatközi megközelítésü területfejlesztési programja jelentette, melyet 2001 tavaszán fogadott el a NYDRFT. A dokumentum meghatározza a régió 2000-2006 intervallumra vonatkozó fejlesztési prioritásait és az azokhoz kapcsolódó intézkedéseket. 2001 során elkészuiltek a regionális program megvalósításának intézkedési szintủ operatív programjai, a regionális programhoz illeszkedő Győr-Moson-Sopron és Vas megyei területfejlesztési programok, valamint kistérségi szinten is számos komplex, illetve ágazati jellegü fejlesztési program került kidolgozásra.

\section{A kutatás célja}

A NYDRFT már az ezredfordulón kezdeményezte a dekoncentrált szervekkel való együttmüködést felismerve, hogy a régió területfejlesztési programja egyes intézkedéseinek megvalósulásához a Tanács hatáskörébe utalt források felhasználásán túlmenöen jelentős ágazati fejlesztések is hozzájárulnak. A dekókkal való együttmúködés azért kiemelt fontosságú, mert az állami fejlesztési források mintegy $90 \%$-áról - dekoncentrált államigazgatási szervek közbeiktatásával, mégis - centralizáltan, minisztériumi szinten döntenek. A különbözö fejlesztési tevékenységek összehangolásával növelhető a fejlesztési források felhasználásának hatékonysága. Ennek érdekében szükséges számbavenni, hogy a közvetlen pénzügyi-finanszírozási decentralizáció mellett milyen összesített forrásrendszerrel rendelkezik a régió. 
Mezei Katalin: Integrált regionális fejlesztés-finanszírozási modell a Nyugat-Dunántúlon.

Tér és Társadalom, 18. 2004. 4. 51-68. $p$.

\section{1. ÁBRA}

A Nyugat-dunántúli területfejlesztési program cél- és intézkedésrendszere (Target and Measure System of the Regional Development Program of West Transdanubia)

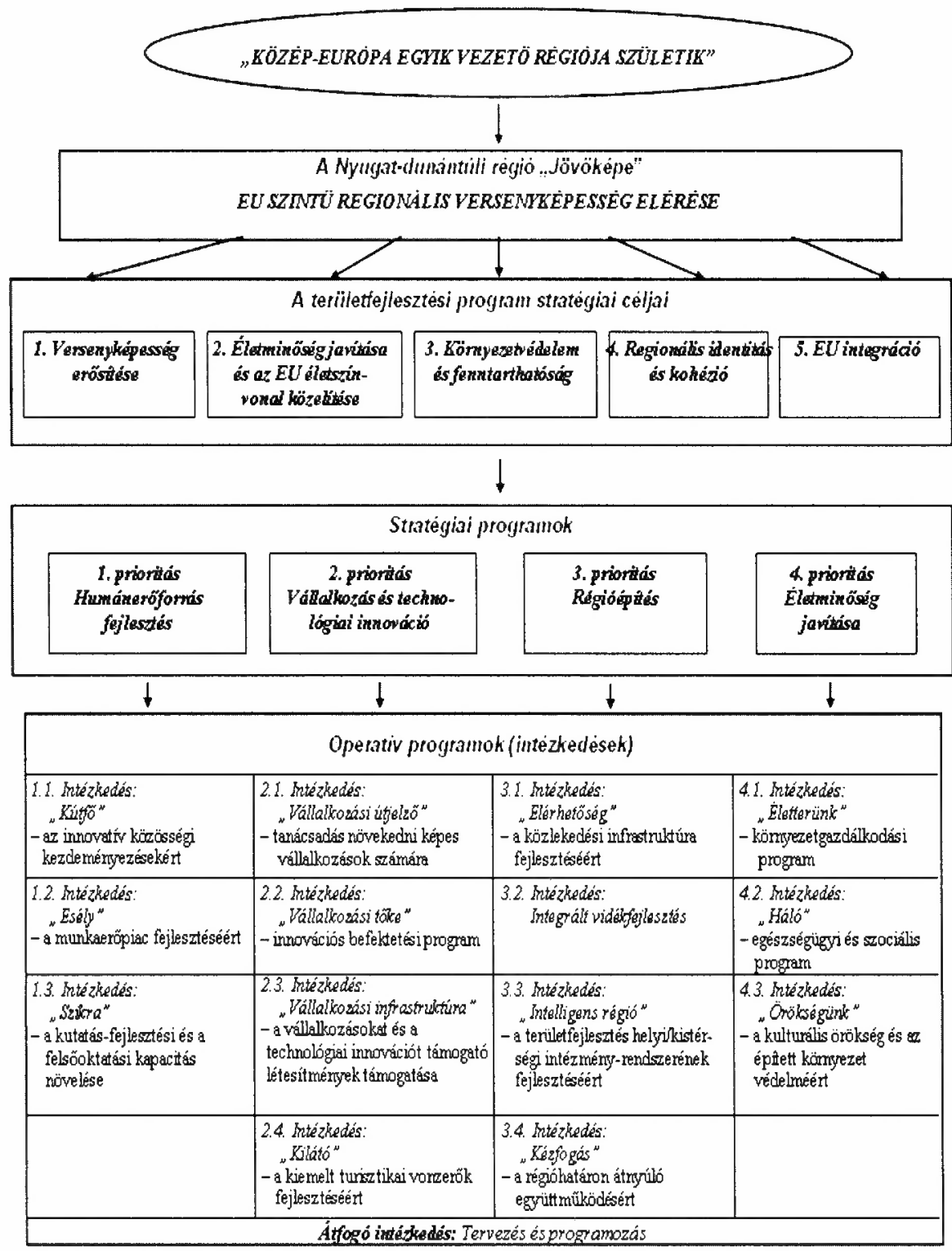

Forrás: A Nyugat-dunántúli régió területfejlesztési programja $(2001,69)$. 
Az integrált finanszírozási modell kidolgozása több, egymáshoz kapcsolódó, egymást feltételező projektelem elkészítését tette szükségessé. Első lépésként a Nyugat-dunántúli régió területfejlesztési célrendszerének bemutatására került sor, melynek során megkerestük a kapcsolódási pontokat a regionális, megyei és kistérségi szintủ ágazati és területfejlesztési programok között. Mivel a Tanács tevékenységének alapdokumentumaként a regionális területfejlesztési programot határozta meg, ezért a tanulmány elkészítése során mi is az e dokumentum által meghatározott programstruktúrát tekintettük kiindulópontnak (1.ábra), és ennek feleltettük meg az alsóbb szintü fejlesztési dokumentumok elemeit.

A Nyugat-dunántúli régió területfejlesztési célrendszere természetesen nem értelmezhető a megvalósítást lehetővé tevő területfejlesztési eszközrendszer ismerete nélkül. Meg kellett tehát határoznunk, hogy az adott területi szinten milyen fejlesztési források álltak rendelkezésre a vizsgált 2000-2003-as időszakban, és hogy ezen kötött felhasználású források a regionális program mely elemeinek megvalósulását támogatták.

A területfejlesztés eszközrendszere rendkívül kiterjedt, annak teljes körủ elemzésére a kutatás során nem vállalkoztunk. Vizsgálataink csupán a 24/2003. Kormányrendelet alapján az összehangolás szabályai alá tartozó területfejlesztési forrásokra, továbbá a területfejlesztésről és területrendezésről szóló 1996. évi XXI. törvényben területfejlesztési célúnak minősített, településfejlesztési forrásokra (cél- és címzett támogatásokra), valamint az Európai Unióból érkező előcsatlakozási forráselemekre terjednek ki.

Az állami támogatási rendszer vizsgálata során nagy hangsúlyt fektettünk a különböző területfejlesztési források kezelésében, illetve felhasználásban részt vevő szervezetek müködési és döntési mechanizmusának bemutatására, különös tekintettel a támogatások összehangolásának kérdésére. (A vizsgált források elosztási mechanizmusok szerinti bontását az 1. táblázat tartalmazza.)

\section{Kutatási hipotézisek}

Tanulmányunk elkészítése során kutatási hipotéziseink a következők voltak:

1) Fejlesztési célok:

A Nyugat-Dunántúl Regionális Fejlesztési Programja EU kompatibilis tervezési dokumentum, abban az értelemben, hogy olyan fejlesztési célokat tartalmaz, amelyek az Európai Unió Strukturális Alapjaiból finanszírozhatóak. A programstruktúra kialakítása során a tervezök nem a teljeskörüségre törekedtek, hanem a regionális fejlesztés azon területeire koncentráltak, amelyek összhangban voltak és vannak az EU regionális fejlesztési politikájával, $s$ ezáltal nemcsak hazai, hanem EU-s forrásokból is finanszírozhatók. A regionális program tehát a tervezök szándéka szerint olyan alapdokumentum, amely EU csatlakozásunk után is bármely további fejlesztési elképzelés kiindulópontja lehet. Ezzel magyarázható, hogy a regionális program intézkedései sokkal specifikusabb tartalommal bírnak a hazai területfejlesztési források által támogatott fejlesztési céloknál. Vizsgálataink ezt a hipotézisünket visszaigazolták. 
2) Fejlesztési források:

Kiinduló feltevésünk nyilván az volt, hogy a területfejlesztéssel kapcsolatba hozható források felhasználásáról településszintü, idősoros adatok állnak rendelkezésre, amelyek egyértelmủ algoritmus alapján megfeleltethetök a regionális program célstruktúrájának. Sajnos ezen hipotézisünk teljes egészében megdölt. Az adatokhoz való hozzáférés erösen korlátozott, ezek területi szintủ bontása egymással sem kompatibilis. Idősorok összeállítása lehetetlen, mivel a legtöbb támogatástípus esetén csak az utolsó két év adatai hozzáférhetök. Az eltérỏ célrendszer okán pedig nem adható meg egyértelmü algoritmus a források regionális program szintű besorolásához.

3) A fejlesztési források összehangolása:

A kérdés kapcsán egyrészt vizsgálnunk kellett, hogy az egyes fejlesztési források éves kereteinek felosztása során az illetékes hatóságok mennyire veszik figyelembe a regionális program által meghatározott, adott ágazatot érintő fejlesztési célokat. Másrészt vizsgálnunk kellett azt is, hogy a hasonló célokat szolgáló fejlesztési források felhasználása során van-e együttműködés a különböző források kezelöi között, vagy társfinanszírozás helyett egymástól független, autonóm beruházások indulnak egymással párhuzamosan.

A fejlesztési források összehangolásának igénye már a regionális program készítése során felmerült. A forrástérkép alapján feltételeztük, hogy a regionális program megvalósítását célzó együttmüködésbe négy nagy rendszer (ágazat) vonható be, környezetvédelem-vízügy, munkaügy, idegenforgalom, közlekedési infrastruktúra. A regionális program tervezése során ugyanis ezen forrásokat kezelö dekoncentrált szervek mutatták a legnagyobb együttmüködési hajlandóságot. A gyakorlati megvalósításnak azonban az esetek többségében komoly törvényi akadályai vannak. Hipotézisủnk csak részben igazolódott vissza. Az együttmúködés sajnos sokkal inkább a szándéknyilatkozatok, sem mint a gyakorlat szintjén müködik.

\section{Kutatási eredmények}

\section{A Nyugat-dunántúli régió területfejlesztési célrendszere}

A Nyugat-dunántúli regionális program célrendszerének kialakítása során az EUkompatibilitás volt a fő szempont; tehát olyan fejlesztési prioritások meghatározására került sor, amelyekhez a Strukturális Alapokból források rendelhetők. A prioritásokon belül az intézkedéslista kialakítása során már nagyobb figyelem irányult a nemzeti támogatásokra, hiszen elöre látható volt, hogy a program megvalósítása döntöen hazai forrásokból fog finanszírozódni. 
Mezei Katalin: Integrált regionális fejlesztés-finanszírozási modell a Nyugat-Dunántúlon.

Tér és Társadalom, 18. 2004. 4. 51-68. p.

TÉT XVIII. évf. 2004 - 4

Integrált regionális ...

A regionális program forrástérképén több, nagyságrendileg és arányában is jelentős forrás csak kiegészítő jelleggel szerepel. Ennek forrásonként eltérő okai vannak.

- Bizonyos fejlesztési célok azért maradtak ki a regionális programból, mert mind az EU-ban, mind Magyarországon a területfejlesztéstől elkülönített forrásrendszerrel rendelkeznek (pl. agrártámogatások). (Ez a terület csak áttételesen, vidékfejlesztési célként került bele a regionális programba, fejlesztési forrásairól sem sikerült adatot szereznünk.)

- Másodlagos fejlesztési forrásként kezeli a regionális program a megyei szintre decentralizált, MTT-k által elosztott ún. közvetlen területfejlesztési forrásokat is, mivel ezek céljukat tekintve elsősorban a megyei területfejlesztési programok megvalósítását szolgálják. A megyei területfejlesztési programok azonban csak a regionális program jövőképének megvalósítását támogatják, valójában éppen a regionális program komplementereiként müködnek; olyan általános fejlesztési célokat tartalmaznak, amelyek a regionális programba nem fértek bele. Ezt a tervezői szándékot támasztják alá gyakorlati tapasztalataink is. A legtöbb problémát ugyanis a megyei szintre decentralizált fejlesztési források regionális program szintủ megfeleltetése jelentette, mivel a regionális program nem tartalmaz olyan célokat, amiket ezek a források támogatnak (alap- és középfokú oktatási-, szociális- és kulturális intézmények fejlesztése).

\section{A terïletfejlesztési támogatási rendszer müködése}

A magyar területfejlesztési támogatási rendszer nem mondható stabilnak. A területfejlesztési támogatásokról minden évben új kormányrendelet kerül kiadásra, mely különbözỏ szabályozási változásokat tartalmaz. A változások a kedvezményezettek körére és a szabályozás pénzügyi elemeire egyaránt kiterjednek. A változásokban szerepet játszik a források bővülése és az EU normákhoz való alkalmazkodási követelmény egyaránt. A túlzottan gyakori változások azonban csak a rövid távú gondolkodást és a bizonytalanságot erősítik az érintettekben. Megjegyezzük, hogy az EU a jelenlegi fejlesztési programozás keretében mind a támogatásra jogosultak körét, mind a támogatások régiók közti elosztását, mind pedig az alkalmazandó támogatási rátákat 7 évre elöre meghatározza. A jelenlegi helyzetben nyilván nem várható el a kormánytól, hogy olyan 7 éves költségvetést készítsen regionális bontásban, amelynek betartása mellett elkötelezi magát. Az viszont elvárható, hogy a szabályozás alapelvei és elemei legalább az NFT megvalósításának időszakában (2004-2006) ne változzanak (Illés 2002).

A stabilitás hiánya nemcsak a kormányzati szintủ szabályozásban okoz problémát, hanem a területfejlesztési célú, ágazati fejlesztési források elosztásában is. Ezen források pályázati rendszereinek mủködését szabályozó tárcaszintủ rendeletek és határozatok szintén évről évre változnak, ami tovább rontja a támogatási rendszer átláthatóságát. 
Sajnos a támogatások nem alkotnak koherens rendszert. Jelenleg többféle kedvezményezett térségi kategória van, és a különbözỏ eszközök, különbözỏ térségekben különböző mértékben alkalmazhatók.

- Vannak olyan támogatások, amelyek csak kedvezményezett térségekben használhatók fel (Területfejlesztési Céltámogatás - TFC, Vállalkozási övezetek támogatása - VÖC, Kistérségi Támogatási Alap - KITA, Területi Kiegyenlító Támogatás - TEKI, Szociális Kistérségi Felzárkóztatási Program - SZKF). A kedvezményezettek köre azonban minden támogatás esetén más és más.

- A minisztériumok által kezelt fejezeti kezelésủ előirányzatok tekintetében preferált területnek számít az öt legkevésbé fejlett megye (Borsod-AbaújZemplén, Szabolcs-Szatmár-Bereg, Nógrád, Békés, Somogy) egész területe.

- Kereskedelmi banki hitelkedvezmények is csak a preferált ơt megyében megvalósítandó beruházásokhoz vehetők igénybe.

- Az adókedvezmények különböző formái érvényesíthetők a vállalkozási övezetekben, a területfejlesztés kedvezményezett térségeiben és az országos átlagot jelentősen meghaladó munkanélküliséggel sújtott térségekben.

- Sok pályázat eltérő támogatási rátákat határoz meg a kedvezményezettek különbőző csoportjaira vonatkozóan.

A rendszer konzisztenciáját jelentősen rontja az időbeli stabilitás hiánya és a sokféle szabályozó egyưttes alkalmazása.

A területfejlesztési támogatási rendszer múködésének vizsgálata során elöször is meg kellett határoznunk azokat a területi szereplöket, akik saját fejlesztési forrással rendelkeznek, vagy döntési, illetve véleményezési jogosultsággal bírnak állami fejlesztési források felett, hiszen a kutatás elsődleges célja az volt, hogy képet adjon a regionális program megvalósításának előrehaladásáról, ami tervszerủ forrásfelhasználást feltételez az érintettek részéról. Megállapítottuk, hogy sem a kistérségek, sem a helyi és területi önkormányzatok nem bímak döntési jogosultsággal állami fejlesztési források felett. Saját fejlesztési forrással pedig a kistérségek egyáltalán nem, az önkormányzatok pedig csak rendkívül korlátozott mértékben rendelkeznek. Így feltételezhetô, hogy az e források felhasználására vonatkozó prioritások sokkal inkább a meglévő szük keresztmetszetek feloldására irányulnak, semmint stratégiai fejlesztési célokat szolgálnak. Vizsgálataink ebböl kifolyólag a megyei és regionális szintre decentralizált területfejlesztési forrásokra, továbbá a közvetlenül, illetve a dekoncentrált szervek közremúködésével elosztott ágazati és EU-s fejlesztési forrásokra koncentrálódnak.

A területfejlesztési célú ágazati forrásokat az elosztásukban részt vevő területi szereplők döntési kompetenciái alapján több csoportra oszthatjuk (1. táblázat). 
Mezei Katalin: Integrált regionális fejlesztés-finanszírozási modell a Nyugat-Dunántúlon.

Tér és Társadalom, 18. 2004. 4. 51-68. p.

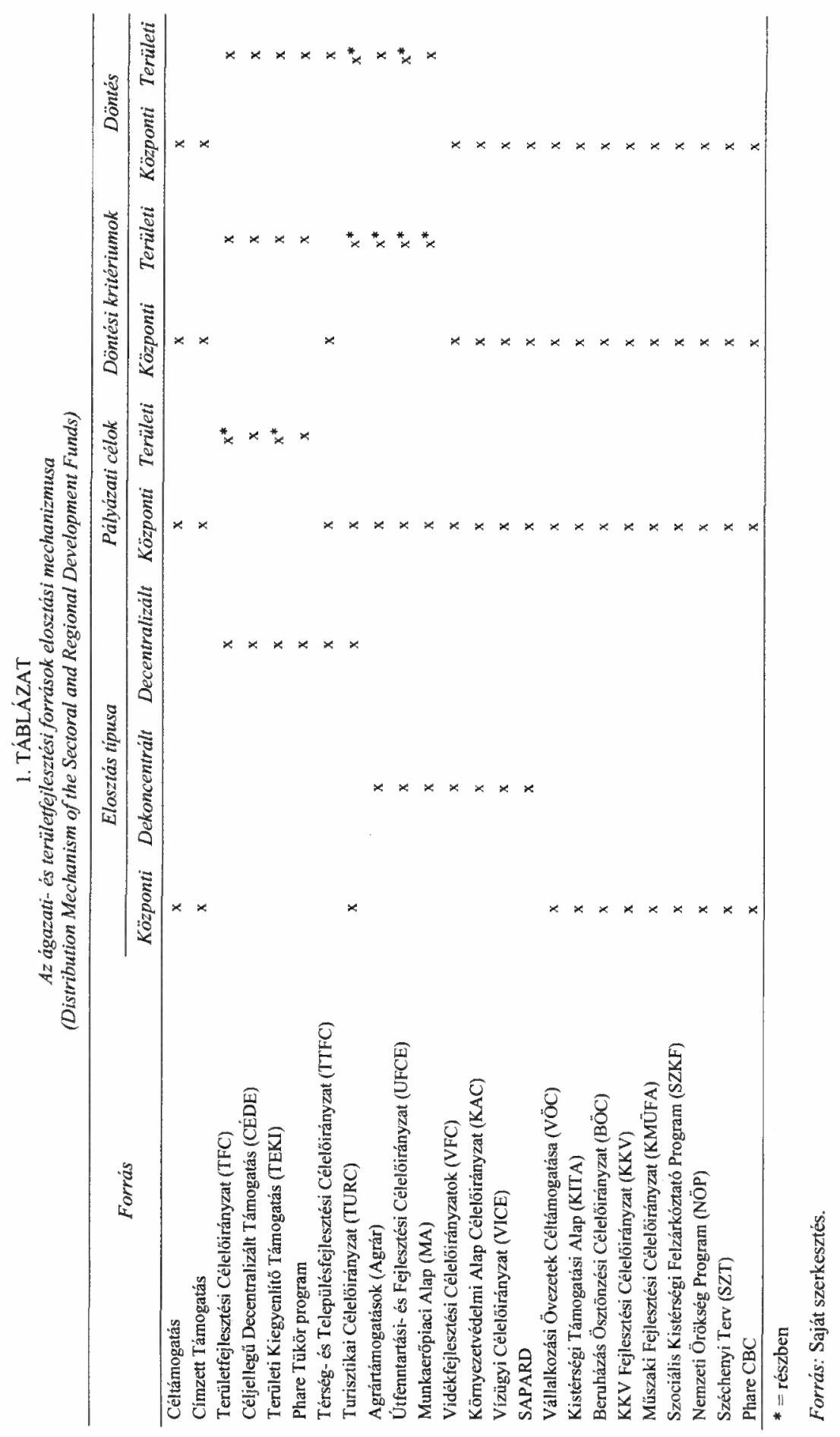


- Vannak olyan, az összehangolás szabályai alá eső területfejlesztési források, amelyek elosztása során a területi szereplök véleményezési joggal sem rendelkeznek, ilyenek a Nemzeti Kulturális Örökség Minisztériuma (NKÖM) kezelésében lévő Nemzeti Örökség Program, a Gazdasági és Közlekedési Minisztérium (GKM) kezelésében lévő források (Gazdaságfejlesztési-, majd Beruházás-ösztönzési és KKV Fejlesztési Célelöirányzat, a Központi Turisztikai Célelöirányzat [TURC]) és az Oktatási Minisztérium (OM) kezelésében lévö Müszaki Fejlesztési Célelőirányzat (KMÜFA).

- Vannak olyan források, amelyek elosztása során területi szempont csak azáltal érvényesül, hogy fejlettségi mutatók alapján korlátozott a támogatás kedvezményezettjeinek köre, elosztásuk azonban centralizált; területi szereplöt a döntésbe nem vonnak be. (A Miniszterelnöki Hivatal $[\mathrm{MeH}]$ kezelésében lévő Vállalkozási övezetek [VÖC] támogatása és a Kistérségi Támogatási Alap [KITA], valamint az ESZCSM kezelésében lévö, Szociális kistérségi felzárkóztatási program [SZKF]).

- A fejlesztési források következỏ csoportját azok az ágazati források jelentik, amelyek esetén a pályázati kírások központilag meghatározott (országos szinten azonos) fejlesztési célokat tartalmaznak, ugyanakkor a pályázatok összegyüjtése és elővéleményezése (Környezetvédelmi Alap Célelőirányzat [KAC], Vízügyi Célelőirányzat [VICE] - Környezetvédelmi Felügyelöségek, cél- és címzett támogatás [CCT] - Megyei Területfejlesztési Tanács [MTT]), illetve elbírálása (Agrártámogatások - Földmúvelésügyi [FM] Hivatalok, Vidékfejlesztési Célelőirányzat [VFC] - Regionális Vidékfejlesztési Iroda [REVI], Munkaerőpiaci Alap [MA] - Megyei Munkaügyi Központok [MMK]) dekoncentrált szerveken keresztül történik.

- Két olyan ágazati fejlesztési forrást találtunk, ahol a pályázatok fejlesztési céljainak kijelölésében is effektíve részt vesznek a pályázatok kezelését végző területi szervek (decentralizált TURC - Regionális Idegenforgalmi Bizottság [RIB], Útfenntartási és Fejlesztési Célelőirányzat [UFCE] - Megyei Közlekedési Felügyelet mint végfelhasználó).

A decentralizált fejlesztési források olyan támogatási keretek, amelyek felhasználásról a kezelésükkel megbízott területi szereplök saját hatáskörben dönthetnek.

- Kisebb szabadságfokkal rendelkeznek a Megyei Területfejlesztési Tanácsok, hiszen az általuk kezelt Területi Kiegyenlító Támogatás (TEKI) és Területfejlesztési Célelőirányzat (TFC) pályázatokban a jogszabály által elöírt célokat kell meghirdetniük, ugyanakkor saját hatáskörben határozhatják meg a döntési kritériumokat. A Céljellegủ Decentralizált Támogatás (CÉDE) esetében pedig önállóan határozhatják meg a pályázati célokat is.

- A Regionális Fejlesztési Tanács a Phare Tükörprogramokhoz kapcsolódó pályázatok meghirdetése (2001 és 2002) során maga határozhatta meg a pályázati célokat és a kiválasztási szempontokat egyaránt, ugyanakkor a Térség- és 
Mezei Katalin: Integrált regionális fejlesztés-finanszírozási modell a Nyugat-Dunántúlon.

Tér és Társadalom, 18. 2004. 4. 51-68. p.

TÉT XVIII. évf. 2004 - 4

Integrált regionális ...

59

Településfejlesztési Célelöirányzat (TTFC) esetében, 2003-ban Kormányrendelet szabályozta országosan egységesen a pályázati felhívásokban szerepeltetendő kritériumokat. Így tehát a területi szereplöknek a fejlesztési források elosztására vonatkozó szabadságfoka meglehetősen korlátozott volt.

Az ágazati fejlesztési források tekintetében pedig csupán a források dekoncentrálásáról beszélhetünk, hiszen a dekók a központi akarat végrehajtóiként nem csak döntési kompetenciával nem rendelkeznek, de a pályázati célok meghatározásában sincs érdemi szerepük. Márpedig, amíg az ágazati fejlesztési forrásokat kezelö minisztériumok saját dekoncentrált szerveik javára sem hajlandók lemondani döntési kompetenciáikról, addig nehezen elképzelhető, hogy szándékaik komolyak a források összehangolása tekintetében. Tapasztalataink szerint a jelenlegi helyzetet a források összehangolásának hiánya jellemzi. Bár vizsgálataink csak az állami fejlesztési források meghatározott körére, a külön jogszabályban felsorolt területfejlesztési támogatásokra terjednek ki, mégis úgy látjuk, hogy a magyar támogatási rendszer területfejlesztési szegmensének legnagyobb problémája az átláthatatlanság és a forráskoordináció hiánya.

A sürün változó célelőirányzatok között gyakran tapasztalható átfedés (több forrás is támogatja ugyanazt a célt), Az elöirányzatokat kezelő minisztériumok sokkal inkább sajất belügyükként kezelik a támogatásokat, semmint, hogy a szinergikus hatásokban rejlỏ előnyöket keresnék, az együttmüködési igény csak a szándéknyilatkozatok szintjén érhetỏ tetten. Az ágazati források esetén a pályázati célok összehangolására tárcaközi egyeztetéseken kerül sor, erre a területi szereplöknek nincs ráhatása. Területi szintủ összehangolásra az ágazati források tekintetében nem találtunk példát. Kivéve nyilván a kedvezményezett státuszú öt megyét, ahol az ágazati források elosztását is az MTT-k koordinálják. A fejlesztési célok azonban ez esetben is központilag meghatározottak, területi szempontok legfeljebb az elosztási prioritásokon keresztül érvényesíthetők, ugyanakkor adott a lehetőség a megyei szintre decentralizált forrásokkal való összehangolásra. Ez a lehetőség azonban a Nyugat-dunántúli régiót nem érinti. Tapasztalataink szerint a fejlesztési célok összehangolása effektíve kizárólag az MTT hatáskörbe utalt TEKI és CÉDE esetében működik, ami a két pályázat között egyfajta komplementer viszonyt eredményezett.

A források összehangolására olyan fejlesztéseknél van példa, amelyek akkora beruházás igényủek, hogy egyetlen támogatási forrásból nem finanszírozhatók. A társfinanszírozási kísérlet azonban ezekben az esetekben is sokkal inkább a kényszerhelyzetben lévö pályázó, semmint a pályázatok kiíróinak érdeme. Ráadásul a projektek társfinanszírozása indokolatlanul megnöveli a pályázókra rótt adminisztratív terheket. Elsősorban a megyei szintre decentralizált források elosztása során érzékelhető, hogy az MTT-k azokat a pályázatokat részesítik elönyben, amelyek a tervezett beruházás megvalósításához más forrásokat is igénybe kívánnak venni.

A decentralizált források csupán töredékét teszik ki a területfejlesztési forrásoknak, felhasználásuk szempontjai pedig döntően központilag meghatározottak, így ezek az elóírások inkább a területpolitika általános céljaihoz kapcsolódnak, mint az egyes 
területi egységek fejlesztési elképzeléseihez. A differenciálás éppen az eltérő területi sajátosságok miatt nem lehetséges; a területi egységek speciális szükségleteinek figyelembevétele átláthatatlanul bonyolult pályázati célstruktúrákat eredményezne. Jelen helyzetben viszont csak áttételesen, a központi célrendszer mellett alkalmazott prioritásrangsorok révén érvényesülnek az elosztásban területi szempontok.

Probléma továbbá a túlszabályozottság, ráadásul gyakran változó joganyagot kellene az érintetteknek ismerniük, ami a stabilitás hiányához vezet.

A forráskoncentráció alapelve is sérül azáltal, hogy túlzottan szétforgácsolódnak a fejlesztési források.

A rendszer ellenörzése - a pályázati adatokhoz való korlátozott hozzáférés okán meglehetősen nehézkes, a hatékonyság mérése pedig - az adatok kompatibilitásának hiánya miatt - szinte lehetetlen.

A magyar területfejlesztési támogatási rendszer értékelésekor, ugyanakkor, nem hagyhatjuk figyelmen kívül, hogy ez egy tanuló rendszer, amelynek fő célja a felkészülés az EU-s fejlesztési források fogadására, társfinanszírozására, valamint komplementer nemzeti támogatások kidolgozása olyan fejlesztésekre, amelyek a Strukturális Alapokból nem finanszírozhatók. Egy tanuló rendszer pedig, melynek müködőképességét egy turbulensen változó politikai, gazdasági, társadalmi, jogi környezetben kell biztosítani, természetszerüleg hordozza magán a folyamatos változás jeleit. Ugyanakkor az együttmüködés hiánya nyilván nem írható a környezet rovására, kialakulása határozott politikai akaratot feltételez (Mezei 2003).

\section{Területfejlesztési források a Nyugat-Dunántúlon (2000-2003)}

A Nyugat-Dunántúl fenti időszakra vonatkozó forrástérképének összeállítása rengeteg nehézséget okozott, amelyeket csak részben sikerült megoldani. Sajnos, a 2000. évre vonatkozóan az ágazati fejlesztési források többségéröl minden igyekezetünk ellenére sem sikerült adatot szereznünk. Ugyanakkor 2001-2003 tekintetében adatbázisunk teljesnek tekinthetöo ${ }^{2}$, így elemzéseinket erre az időszakra vonatkozóan készítettük el. Ezen időintervallum vizsgálatát indokolja az a körülmény is, hogy a Nyugat-Dunántúli Regionális Területfejlesztési Program csak 2000 szeptemberében került elfogadásra, tehát abban az évben egyetlen területi szereplö sem vehette még érdemben figyelembe ajánlásait a források elosztása során.

Az adatbázis hiányosságai ellenére készítettünk egy kimutatást a 2000-2003-as időszak nyertes pályázatairól. Eszerint a régió szereplői 2000-2003 között 2700 sikeres pályázatot nyújtottak be ${ }^{3}$. Az egyes pályázatokon elnyerhető összegek rendkívül eröteljesen, 70 ezer Ft és 1,98 milliárd Ft között szóródnak. Az átlagosan elnyert támogatási összeg 24 millió Ft volt. Összesen 313 átlagos érték feletti pályázatot találtunk, összértékük közel 54 milliárd forintot tett ki. Tehát a pályázók $11 \%$-a nyerte el a Nyugat-Dunántúlra érkező támogatások ${ }^{4} 75 \%$-át.

A Nyugat-dunántúli régió részesedését a területfejlesztési forrásokból (az adott évi költségvetési törvényben meghatározott célelőirányzati keretösszegböl) a 2. táblázat tartalmazza ${ }^{5}$. 
Mezei Katalin: Integrált regionális fejlesztés-finanszírozási modell a Nyugat-Dunántúlon.

Tér és Társadalom, 18. 2004. 4. 51-68. $p$.

TÉT XVIII. évf. 2004 - 4

Integrált regionális ...

61

\section{TÁBLÁZAT}

A Nyugat-dunántúli régió részesedése a terïletfejlesztési forrásokból (2001-2003)

(Participation of the West Transdanubian Region from the Regional Development

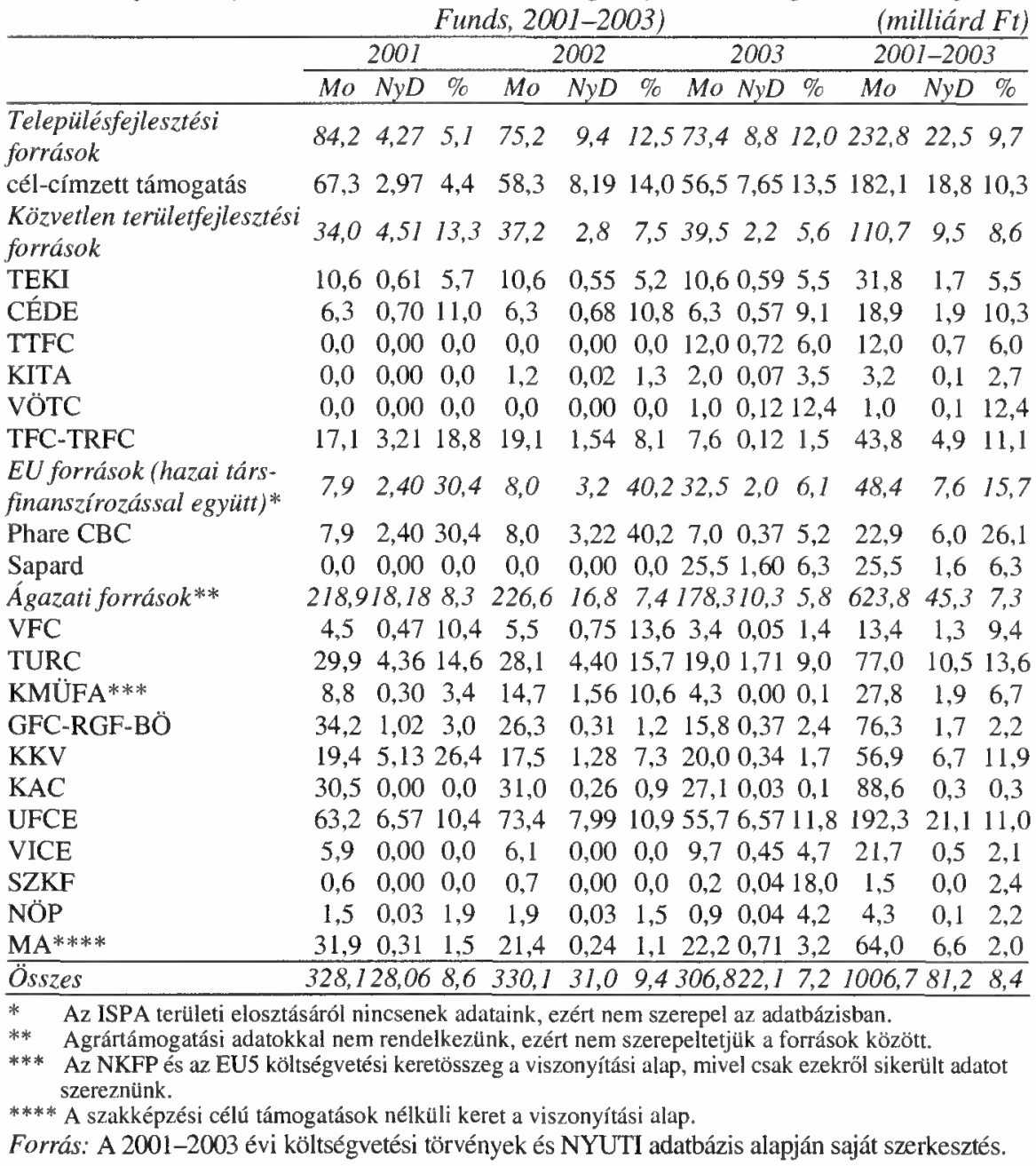

$\mathrm{Az}$ adatok tanúsága szerint a Nyugat-dunántúli régió részesedése a területfejlesztési forrásokból (a Phare CBC forrásokkal együtt) a 2001-2003-as évek átlagában $8,4 \%$, ami $2 \%$-kal alacsonyabb a régiót lakosságarányosan megilletỏ részaránynál, ugyanakkor $1 \%$-kal magasabb a törvényhozó által, a régió fejlettségi mutatói alapján meghatározott (hazai forrásokra vonatkozó) méltányossági szintnél ${ }^{6}$. Átlag alatti a régió részesedése az összes forrás kétharmadát kitevó ágazati fejlesztési források tekintetében, ugyanakkor az átlagos érték kétszerese az EU-s források esetén, ami annak köszönhetö, hogy a Phare $\mathrm{CBC}$ keret negyede a régióban került felhasználásra ${ }^{7}$.

Ha a területfejlesztési források költségvetési kereteit összevetjük a Nyugatdunántúli tényadatokkal, a településfejlesztési források tekintetében is szignifikáns, 
$5 \%$ fölötti különbséget találunk, ami a régiónak a cél és címzett támogatásokból való átlag feletti, 23\%-os részesedésének köszönhetö ${ }^{8}$.

Az ágazati forrásokon belül is komoly aránytalanságok tapasztalhatók. A Nyugatdunántúli régió által megszerzett összes ágazati forrás negyedét teszik ki az UFCE források, ami 6\%-kal magasabb a költségvetésben elöirányzott mértéknél. Ugyancsak meghaladja a költségvetésben elöirányzott arányokat a régió TURC-ból való részesedése. Ugyanakkor a felzárkóztató célú ágazati fejlesztési forrásokból (KAC, VICE, MA) való részesedés jóval az országos átlag alatt van.

Az adatokból az is kiderül, hogy a vizsgált 2001-2003-as időszakban a Nyugatdunántúli régióban a területfejlesztési hatású források $11 \%$-a került decentralizáltan elosztásra, ami az EU-s elvárásokhoz képest rendkívül alacsony arány, föleg ha azt is figyelembe vesszük, hogy adatbázisunk korábban jelzett hiányosságai miatt ezek a források valószínúleg túlreprezentáltak a mintánkban. (A fejlesztési források öszszetételét a 2. ábra szemlélteti. )

\section{2. ÁBRA}

A Nyugat-Dunántúl fejlesztési forrásainak összetétele

(Composition of Development Funds in the West Transdanubian Region)

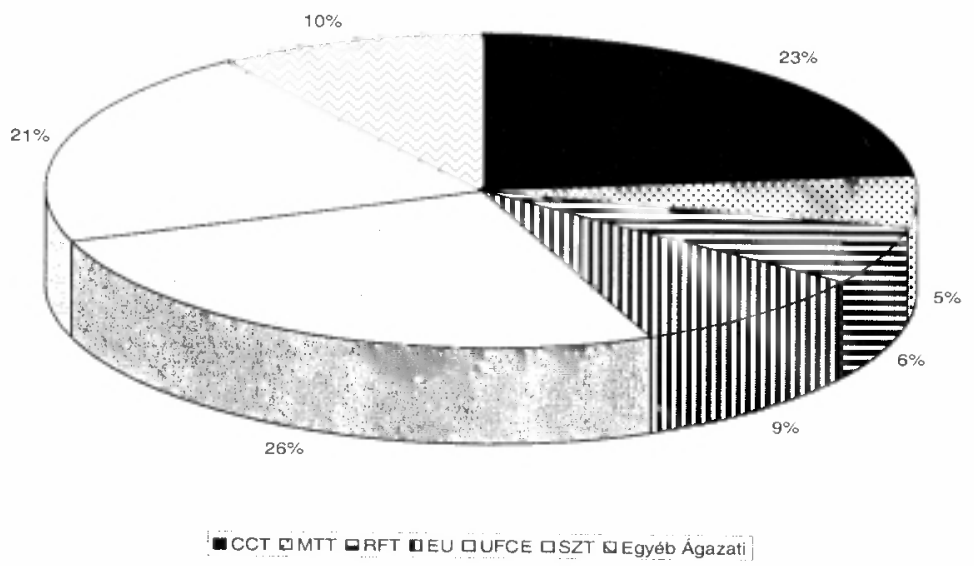

Forrás: Saját szerkesztés.

A Nyugat-dunántúli régió által 2001-2003 során felhasznált területfejlesztési forrásokat a regionális program struktúrájában a 3. táblázat tartalmazza.

A táblázat adatai alapján a regionális program megvalósításának pénzügyi támogatottságáról a következö megállapításokat tehetjük:

2001-2003 között összesen 81 milliárd forint értékủ területfejlesztési forrás érkezett a Nyugat-dunántúli régióba. Ez az összeg nem egyenletesen oszlott el a regionális program prioritásai és intézkedései között. A források 30\%-a a közúti közlekedési infrastruktúra fejlesztését (Elérhetöség - Régióépítés), míg további 18\% környezetvédelmi fejlesztéseket (Életterünk - Életminőség), többnyire a települések ivó- és szennyvíz hálózatának kialakítását szolgálta, ami összesen 2 intézkedési területet fed le a regionális programból. 
Mezei Katalin: Integrált regionális fejlesztés-finanszírozási modell a Nyugat-Dunántúlon.

Tér és Társadalom, 18. 2004. 4. 51-68. p.

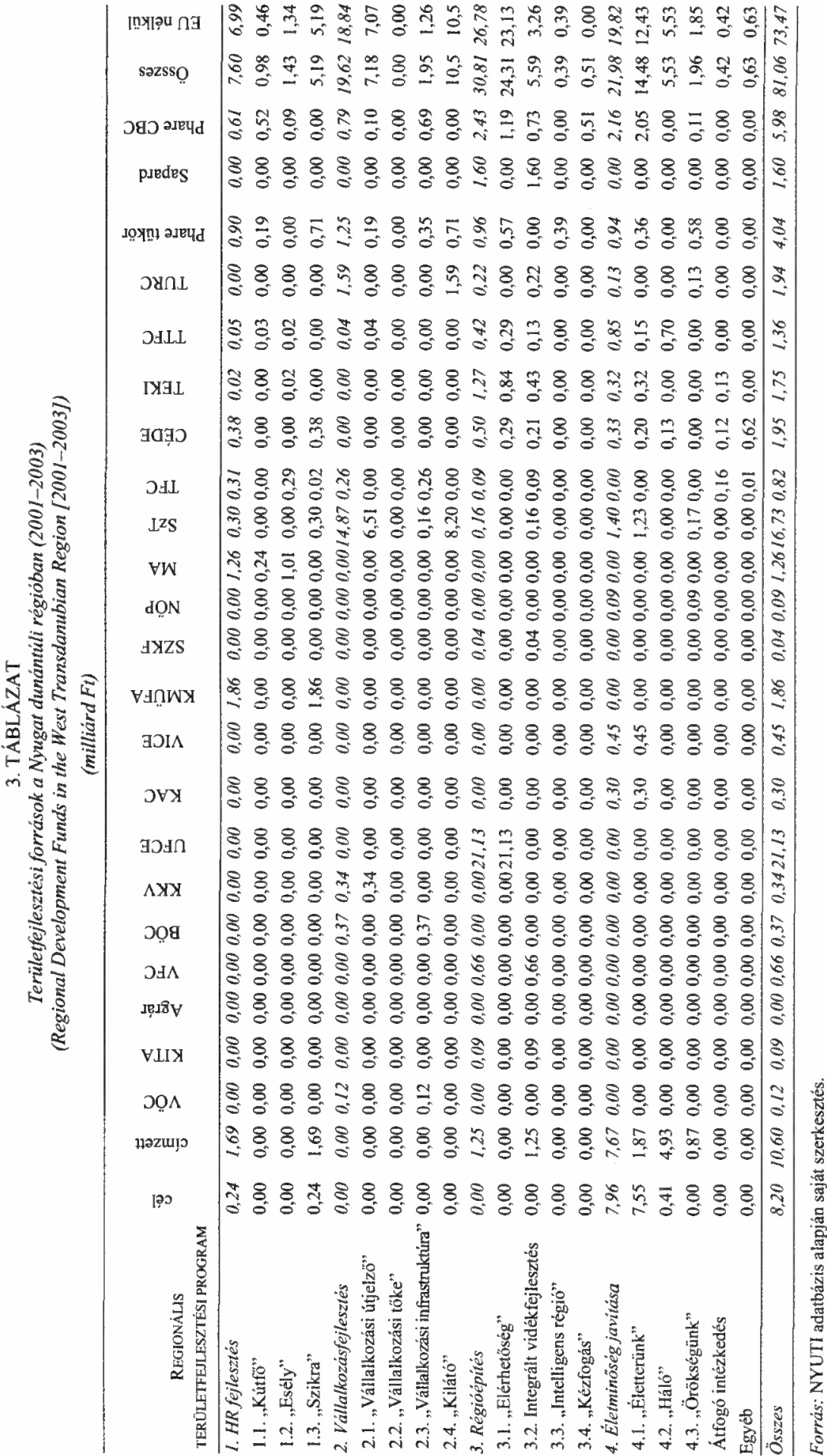


Mezei Katalin: Integrált regionális fejlesztés-finanszírozási modell a Nyugat-Dunántúlon.

Tér és Társadalom, 18. 2004. 4. 51-68. $p$.

Elgondolkodtató, hogy a területfejlesztési források közel fele az alapinfrastruktúra kiépítését szolgálja az ország egyik legfejlettebb régiójában.

A fennmaradó források közel fele (az összes forrás $24 \%$-a) a vállalkozások fejlesztésére fordítódott (Vállalkozásfejlesztés), ezen belül is preferáltak voltak a KKV-k és a turizmus (első sorban a gyógy- és termálturizmus) területén tevékenykedök.

Átlagosnak tekinthetỏ a humán infrastruktúra-, a vidék- és egészségügy-fejlesztés területére fordított összegek aránya (bár megjegyezzük, hogy ezen belül is elsősorban alapvetö és nem speciális fejlesztésekre került sor).

A többi intézkedés támogatottsága átlag alatti; egy intézkedés megvalósítását semmilyen forrás nem támogatta (Vállalkozási töke), egy továbbinak pedig a források csökkenése, illetve megszünése okán komoly veszélybe került a megvalósítása (Intelligens régió).

A forrásfelhasználás szerkezetét a 3. ábra mutatja. E szerint a prioritások közül legkisebb a Humánerőforrás fejlesztés támogatottsága $(9 \%)^{9}$. Legnagyobb a támogatottsága a Régióépitési prioritásnak (38\%), ami elsősorban az UFCE közel 22 milliárdos forrásának köszönhetö ${ }^{10}$. A másik két prioritás támogatottsága átlagosnak minősíthető (Vállalkozásfejlesztés $24 \%$, Életminőség javítás 27\%). Az átfogó intézkedések részesedése $0,6 \%$ körüli, s csupán a források $1 \%$-át nem sikerült egyértelmủen a program struktúrájába illeszteni.

Összességében megállapíthatjuk, hogy a vizsgált időszakban jelentős mennyiségủ területfejlesztési forrás érkezett a Nyugat-dunántúli régióba. A források decentralizáltságának mértéke azonban nem érte el a kívánatos szintet, a megvalósult fejlesztések pedig a források összehangolásának hiányában egymástól elszeparálódva valósultak meg, szinergikus hatást köztük nem tudtunk kimutatni.

3. ÁBRA

A forrásfelhasználás szerkezet a Nyugat-Dunántúlon, 2001-2003

(Structure of the Funds Utilization of the the West Transdanubian Region, 2001-2003)

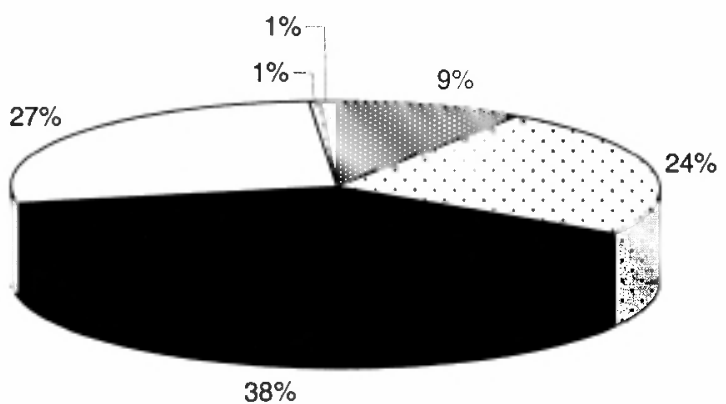

$38 \%$ i. 1. Humánerőforrás fejlesztés

प2. Vállalkozásfejlesztés és technológiai innováció

3. Régióépítés

ロ4. Életminőség javítása

Átfogó intézkedés: tervezés, programozás, régiómarketing 口egyéb

Forrás: Saját szerkesztés. 
Mezei Katalin: Integrált regionális fejlesztés-finanszírozási modell a Nyugat-Dunántúlon.

Tér és Társadalom, 18. 2004. 4. 51-68. $p$.

TÉT XVIII. évf. 2004 - 4

Integrált regionális ...

65

\section{A támogatási rendszer továbbfejlesztésére irányuló javaslatok}

A támogatási rendszer továbbfejlesztésére irányuló javaslataink döntően kormányzati kompetenciákat érintenek, megvalósításuk egységes politikai akaratot és kormányzati fellépést igényel. A területi szereplök feladata ezen a téren, hogy minden lehetséges fórumon egységes fellépéssel képviseljék közös érdekeiket.

- Területi szintenként el kell határolni a területfejlesztési feladatokat. Ennek alapja lehet a fejlesztések területi hatása, azok koncentrált jellege, volumene, a kedvezményezettek köre, illetve a szubszidiaritás elve. A feladat megosztásnak együtt kell járnia a fejlesztési források fokozott decentralizációjával a jelenleg alkalmazott dekoncentrációs elv helyett.

- Minél elöbb meg kell szüntetni a közvetlen területfejlesztési támogatások felhasználásának központi elöírásait. Felhasználásukat teljes egészében a területi egységek kompetenciájába kell utalni, csak így biztosítható a területi szintủ fejlesztési koncepciók és programok megvalósítása.

- Következetesen érvényesíteni kell a területi elvet az ágazati fejlesztési források felhasználásában is, lehetőség szerint a decentralizált források számának növelésével, ellenkezỏ esetben pedig a dekoncentrált szervek kompetenciáinak növelésével.

- A lehető leggyorsabban biztosítandó az alapok, célelöirányzatok közötti idöbeni és tartalmi koordináció, a pályázati feltételek harmonizációja mellett.

- Ellenörizhetöségi és összehasonlíthatósági szempontból nagyon fontos a pályázatok nyilvántartási rendszerének egységesítése, összekapcsolása, valamint a pályázatokon a területi jelleg és felhasználási mód egyértelmú megjelenítése.

Az integrált regionális fejlesztés-finanszírozási modell müködtetésével kapcsolatos javaslatok:

- A modell müködésének alapfeltétele, hogy a tárcák tegyék lehetővé a területfejlesztési támogatások pályázati adataihoz való hozzáférést, a területi vizsgálatok elvégzése érdekében. Az idösoros elemzésekhez legalább öt év adataira lenne szükség, ami megegyezik a pályázati dokumentumok megőrzésére elöírt intervallummal. A pályázati nyilvántartási rendszer egységesítésére és a területi jelleg megjelenítésére vonatkozó fenti javaslatunkat itt fokozottan érvényesnek érezzük.

- Célszerü lenne, ha a pályázati adatokat minden tárca azonos struktúrában közölné, hiszen a jelenlegi kimutatások jelentősen eltérnek egymástól információtartalomban. Fontosnak tartjuk, hogy a pályázatkezelök (központi és területi szinten egyaránt) az eredmények közlése során kitérjenek arra, hogy az adott támogatás, az adott célelőirányzaton belül mely fejlesztési cél megvalósítását szolgálja. Az egységes pályázatkezelői besorolás ugyanis nagymértékben csökkentheti a modell szubjektivitását. 
- A területi vizsgálatok elvégzését nyilván megkönnyítené, ha az adatok területi bontásban állnának rendelkezésre. Ebben nagy segítséget jelentene, ha a tárcák területi dekoncentrált szervei visszajelzést kapnának az általuk kezelt, illetékességi körükbe tartozó pályázatok eredményeiről. Ennek előfeltételeként biztosítani kell, hogy a területfejlesztési intézményrendszer és a tárcák dekói azonos (NUTS alapú) területi besorolás alapján müködjenek. Jelenleg ugyanis komoly eltérések tapasztalhatók ezen a téren, így az egyes tárcák területi kimutatásai egymással nyilván nem kompatibilisek.

- Fokozott együttmúködés kialakítása szükséges területi szinten is, elsősorban az RFT-k és a régiókban müködö dekoncentrált szervezetek között: mind a pályázati felhívások előkészítése, a célok összehangolása, a döntéshozatal és az információáramlás terén. Ez alapvető feltétele egyúttal a régiók megfelelő felkészülésének az önálló operatív programok végrehajtására 2007-töl.

- A felállított modell tökéletesen alkalmas a területfejlesztési támogatási rendszer múködési mechanizmusának elemzésére. A támogatási rendszer évröl évre számottevő mértékben változik, amelynek komoly következményei vannak a támogatások területi és ágazati arányaiban egyaránt. Erre az elmúlt három évre vonatkozóan végzett modellszámítások világosan rámutatnak. Mivel az NFT megvalósításának elkövetkezendö időszakában a támogatási rendszer várhatóan jelentős változásokon fog keresztülmenni, ezért elengedhetetlenül fontos e változások hatásának folyamatos nyomon követése. A modell országos szintü kiterjesztése pedig érdemben tudna hozzájárulni az ország területi folyamatainak elemzéséhez, a forrásfelhasználás hatékonyságának növeléséhez.

\section{Jegyzetek}

${ }^{1}$ Háttértanulmány: 157. NYUTI Közlemény: Integrált regionális fejlesztés-finanszírozási modell. Témavezetö: Lados Mihály, Györ, 2004.

${ }^{2}$ Csupán az agrártámogatási adatok hiányoznak az adatbázisból permanensen. A költségvetési keretszámokból kiindulva ez a támogatási forma teszi ki a területfejlesztéssel kapcsolatba hozható források több, mint $17 \%$-át. Ez akkora pénztömeg, ami jelentösen módosíthatná, söt torzíthatná az arányokat. Ugyanakkor hiányát részben kompenzálja, hogy vannak a mintában egyéb mezögazdasági és vidékfejlesztési célokat támogató források, mint pl. a VFC vagy a Sapard. Hiányoznak továbbá a 2001-es KAC, valamint a 2001-2002-es VICE adatok vonatkozásában a VICE adatok is, ezek azonban csak nem egész 3\%-át teszik ki az összes területfejlesztési forrásnak, tehát minimális hatással lennének a forrásszerkezetre. Söt velük kapcsolatban még inkább igaz, hogy vannak a mintában más, hasonló célokat támogató források (CCT. TEKI, CÉDE).

3 Megjegyezzük, hogy a VFC 2000, 2001, 2003, RIB-TURC 2000-2002, UFCE 2000-2003, KAC 2000-2001, VICE 2000-2002, NKFP 2003, MA központi 2000-2002, MA Vas, Zala 2000-2003, valamint CÉDE, TEKI, TFC 2000-2002 vonatkozásában nem állnak rendelkezésünkre település soros adatok.

${ }^{4}$ UFCE nélküli értéken számolva.

${ }^{5}$ Természetesen tisztában vagyunk azzal, hogy a költségvetési keretszámokhoz viszonyítani nem a legszerencsésebb megoldás, hiszen a tárcák elözō évekröl áthúzódó kötelezettségvállalásai és adott évi tartalékképzése nyilván csökkenti a célelőirányzatok szabadon felhasználható keretösszegeit. Illés Iván (2002) vizsgáłatai szerint az 1996-2002 közti időszakban a közvetlen területfejlesztési források keretösszegeinek csak 10-30\%-a került valóban az adott költségvetési évben felhasználásra. Ha viszont a következö évekre megítélt támogatásokat is az adott évi felhasználás részének tekintjük (ahogy adattábláinkban mi is tettük) a keretösszeget jól közelítő értékeket kaptuk. 
Mezei Katalin: Integrált regionális fejlesztés-finanszírozási modell a Nyugat-Dunántúlon.

Tér és Társadalom, 18. 2004. 4. 51-68. p.

${ }^{6}$ Megjegyezzük, hogy az EU-s források nem módosítják jelentősen az arányokat, nélkülük a 8,4\%-os költségvetési részesedés $8 \%$-ra módosul, így megállapításainkat továbbra is helytállónak érezzük.

${ }^{7}$ Megjegyezzük, hogy a Phare СBC keretek felhasználásában (nem a valós utalásokban, hanem már a döntések meghozatalában is) átlagosan két éves csúszások vannak, tehát nem a legszerencsésebb az adott évi költségvetési kereteket tekinteni összehasonlítási alapnak. A VÁTI adatai alapján azt mondhatjuk, hogy a megítélés évét tekintve a 2000-2003-as időszakban az 55 millió eurós keretböl közel 35 millió eurónak (tehát a támogatási keret $60 \%$-a) a régió volt a kedvezményezettje. A támogatási keretek viszzont nyilván nem kerültek teljes egészében elköltésre, de a konkrét felhasználási értékeket sajnos nem ismerjük. Mindenesetre valószínüsíthető, hogy a régió részesedése a $\mathrm{CBC}$ keretek valós felhasználásából nagyobb a fent jelzett $26 \%$-nál.

Ennek hátterében valószínüleg nem az eltérô támogatási arányok állnak, hiszen a településfejlesztési források hasonló (30-70\%-os) támogatási intenzitásokat írnak elő. Ugyanakkor a tényadatok alapján úgy látjuk, hogy a támogatás mértékére vonatkozó törvényi elöírások betartása eléggé esetieges (pl. bár a címzett támogatásoknál a törvény $40-50 \%$-os támogatotıságot ír elö, a gyakorlatban nem ritkák a 90\%-ban támogatott projektek). Így a CCT-böl való magas támogatottsági arány valószínüleg az e forrásból támogatott projektek magas költségigényének, és ezáltal a pályázó ơnkormányzatok nagyobb önerỏ vállalási képességének tudható be.

${ }^{9}$ Ennek elsödlegesen az adatbázis hiányosságaiból adódó okai vannak, bár megjegyezzúk, hogy a hiányzó adatok kevésbé változtatnák a prioritás támogatottságát, sokkal inkább a prioritáson belüli arányokra lennének hatással.

${ }^{10}$ Ez a forrás nagyságrendjénél fogva torzító hatású, akár figyelembe vesszük a számításoknál, akár nem. Jellemzö, hogy UFCE nélküil a Régioépitési prioritás támogatottsága 17\%-ra esik vissza.

\section{Irodalom}

Beszámoló az Országos Terïletfejlesztési Tanács részére a TFC, TEKI, CÉDE támogatások 2000. évi döntéseiröl. (2001) Kézirat. Budapest.

Beszámoló az Országos Terïletfejlesztési Tanács részére a TFC, TEKI, CÉDE támogatások 2001, évi döntéseiröl. (2002) Kézirat. Budapest.

Beszámoló az Orszagos Területfejlesztési Tanács részére a decentralizált TFC, TEKI, CÉDE támogatások 2002, évi döntéseirôl. (2003) Kézirat. Budapest.

Edelényi B. (2001) Pályázati értékelö rendszerek. - Lados M. (témavezető) A gazdasági-társadalmi hatásvizsgálatok és értékelések. Zárótanulmány. MTA RKK NYUTI, Györ. 45-52. o.

Grosz A. (2001) A decentralizált terïletfejlesztési források felhasználása a Nyugat-dunántúli régióban. Kézirat. MTA RKK NYUTI, Györ.

Grosz A. (2002) A területfejlesztés megyei eszközeinek felhasználása Györ-Moson-Sopron megye kistérségeiben. Kézirat. MTA RKK NYUTI, Györ.

Illés I. (2002) A területfejlesztés eszközrendszerének értékelése és továbbfejlesztési javaslatai. Kutatási zárótanulmány. MTA RKK DTI, Pécs.

Jelentés a terilleti folyamatok alakulásáról és a terilletfejlesztési politika érvényesüléséról és az OTK végrehajtásáról. (2001) A Magyar Köztársaság Kormánya, Budapest.

Kovács T. (2003) A területfejlesztési támogatási források felhasználásának hazai rendszere. - Süli-Zakar I. (szerk.) A terület-és településfejlesztés alapjai. Dialóg Campus, Budapest-Pécs.

KSH (1997) Területi statisztikai évkönyv 1996. KSH, Budapest.

KSH (2002) Terïleti statisztikai évkönyv 2001. KSH, Budapest.

KSH (2003) Terilleti statisztikai évkönyv 2002. KSH, Budapest.

Lados M. (témavezető) (2001) A Nyugat-dunántúli régió területfejlesżési programja. Kézirat. MTA RKK NYUTI, Györ.

Lados M. (témavezetỏ) (2004) Integrált regionális fejlesztés-finanszírozási modell. Kézirat. MTA RKK NYUTI, Györ.

Mezei, C. (2003) The role of the state subsidies in the regional development. - Hajdú, Z. -Pálné Kovács, I. (eds.) Portrait of South Transdanubia: a Region in Transition. MTA RKK, Pécs.

VÁTI (2001) Pénzügyi eszközök - Háttéranyag a területi folyamatok alakulásáról, a terilletfejlesztési politika érvényesülésérốl és az országos teriiletfejlesztési koncepció végrehajtásáról szóló országgyülési jelentéshez. Kézirat. Budapest.

VÁTI (2002) A területfejlesztést közvetve és közvellenül szolgáló támogatási rendszerek és azok segitségével megvalósuló fejlesztésekröl készülő területi értékelések módszertana. Kézirat. Budapest. 


\title{
INTEGRATED FINANCE MODEL FOR REGIONAL DEVELOPMENT IN WEST TRANSDANUBIA
}

\begin{abstract}
KATALIN MEZEI
The study is a summary of the findings of a research carried out in September 2003 - April 2004 by the West Hungarian Research Institute of the Centre for Regional Studies, Hungarian Academy of Sciences, commissioned by the West Transdanubian Regional Development Council. The objective of the research was the foundation of an integrated regional level development policy that contributes to the significant expansion of the co-operation among the West Transdanubian Regional Development Council and the sectoral deconcentrated organs, and to the coordinated and efficient use of the EU and Hungarian resources available for the region in the 2004-2006 period. In the framework of the research we surveyed what sectoral and regional development resources arrived at the region of West Transdanubia in 2000-2003, which elements of the regional programme and to what extent were financed from these resources, what the distribution mechanism of the resources was like and what steps the stakeholders made in order to coordinate the resources.
\end{abstract}

